\title{
Rom i planleggingsperspektiv
}

\begin{abstract}
Artikkelen drøfter ulike rombegrep som brukes - ofte implisitt - $i$ by- og regionplanlegging. Planleggeres fokus på rommets betydning varierer med planleggingens tema og formål. Rom ses dels som noe som muliggjør, letter, vanskeliggjør eller hindrer ulike typer menneskelig aktivitet, dels som noe som påvirker atferd gjennom symbolske og estetiske uttrykk, dels som noe som påvirker våre oppfatninger om hvilke institusjoner, befolkningsgrupper og individer som har makt og status, dels som noe som appellerer til estetisk smak, behag og identifikasjon av gruppetilhørighet, og dels som natur. By- og regionplanleggingens problemstillinger er tverrfaglige, og planleggerne må derfor benytte teorier og begreper fra ulike felt for å forstå situasjonene de arbeider med. Derfor har de også bruk for å kombinere ulike rombegrep: absolutt rom, relativt rom, relasjonelt rom, opplevd rom og sosialt konstruert rom.
\end{abstract}

Nøkkelord: rom, planlegging, kombinasjon, tverrvitenskap

\section{Innledning}

I denne artikkelen ${ }^{1}$ vil jeg rette oppmerksomheten mot den offentlige planleggingens rombegrep. Jeg vil argumentere for at denne planleggingen har bruk for å benytte rombegreper fra ulike disipliner og tradisjoner. Dette fordi de mange ulike emnene og interessene denne planleggingen omfatter, ikke kan fanges opp innenfor en enkelt disiplins eller faglig tradisjons begrepsapparat. Innenfor offentlig planlegging vil jeg først og fremst konsentrere meg om planleggingen etter planog bygningsloven - det som i gamle dager ble kalt by- og regionplanlegging. Offentlig planlegging omfatter også mye annet, utarbeidingen av statsbudsjettet er f. eks. en type offentlig planlegging med vidtrekkende konsekvenser. Vidtrekkende også i bokstavelig forstand, altså romlige konsekvenser: fordelingen av offentlige investeringer er $\mathrm{f}$. eks. ikke uten betydning for flyttestrømmer mellom ulike deler av landet. At planleggingen har romlige forutsetninger og konsekvenser gjelder også innenfor de forskjellige sektorene, slik som f. eks. helsevesenet, undervisningssektoren og energisektoren.

By- og regionplanleggingen er likevel det planleggingsfeltet som mest direkte dreier seg om romlige forhold. I europeisk internasjonalt samarbeid om forskning og utdanning reflekteres dette i at betegnelsen på denne typen planlegging er spatial planning. På norsk benyttes ofte betegnelsen fysisk planlegging, som i praksis ikke bare omfatter de fysiske strukturene, men også de funksjonene og aktivitetene disse strukturene brukes til. Det gjelder også begrepet arealplanlegging, som rent semantisk reduserer rommet til en flate, men som i praksis langt på veg brukes synonymt med fysisk planlegging.

"Spatial planning" er blitt definert som "a method or procedure to influence future allocations of activities to space or space to activities" (Williams, 1996). Det dreier seg altså ifølge Williams, dels om å utvikle nye aktiviteter på konkrete steder, og dels om å skaffe plass til på forhånd gitte aktiviteter. Det første leddet peker i retning av tiltaksplanlegging og regional utviklingsplanlegging, mens det andre dreier seg mer om styring av lokalisering og byggevirksomhet. I land som Norge er lovgrunnlaget og virkemidlene for det siste betydelig sterkere enn for tiltaksplanlegging, som i stadig økende grad har kommet til å dreie seg om å gjøre de ulike lokalsamfunnene, byene og regionene attraktive steder å investere i og flytte til. Ifølge Langdalen (1993) er det ikke nødvendigvis noen motsetning mellom arealplanlegging og tiltaksplanlegging. I dagens nyliberale klima ser det likevel ut til at stadig flere lokale og regionale aktører oppfatter oppmykning av arealplanbestemmelser som et konkurransefortrinn i kampen om å trekke til seg investeringer (Næss, 2008). Det er likevel grenser for hvor mye av arealbruksutviklingen og den fysisk/romlige utviklingen av byer og regioner som kan overlates til markedskreftene uten at grunnlaget for kapitalakkumulasjon undermineres (Klosterman, 1985; Fogelsong, 1996). I diskusjonen nedenfor vil jeg først og fremst konsentrere meg om den delen av 
fysisk planlegging som handler om å styre utviklingen av framtidig arealbruk, bygningsmasse og teknisk infrastruktur.

Grunnspørsmålene i denne typen planlegging er blitt beskrevet slik (Strand, 1991; Næss \& Saglie 2000):

- Til hvilke funksjoner må det skaffes arealer?

- Hvilket omfang av og hva slags arealer behøves til de forskjellige funksjonene?

- Hvordan bør ulike funksjoner lokaliseres i forhold til hverandre?

- Hvordan bør funksjonene forbindes med hverandre?

- Hvordan bør en utforme de fysiske omgivelsene som funksjonene etableres i, for å ivareta både funksjonelle, estetiske, økonomiske, økologiske og trivselsmessige hensyn?

- Hvilke arealer bør beskyttes mot menneskelige inngrep ${ }^{2}$ ?

Et planforslag for arealbruk, bebyggelse og infrastruktur er et konkretisert svar på slike spørsmål. I tillegg til disse spørsmålene dreier by- og regionplanleggingen seg om en rekke spørsmål i tilknytning til den samfunnsmessige planprosessen med befolkningsmedvirkning, forhandlinger, politiske beslutninger og virkemidler for gjennomføring.

Needham (2000:442) karakteriserer romlig planlegging som et designfag i tilsvarende forstand som van Aken (1994, sitert fra Needham, ibid.) bruker denne betegnelsen om fag som arkitektur, medisin, tekniske fag, næringslivsstudier, jus og psykoterapi. Alle disse fagene sikter mot å utvikle kunnskap med tanke på å utforme gjenstander eller forbedre eksisterende situasjoner. Profesjonsutøverne arbeider med å løse kontekstavhengige og spesifikke problemer, der hun eller han analyserer problemet, utformer virkemidler for å håndtere problemet, tar disse midlene $\mathrm{i}$ bruk (eller anbefaler en oppdragsgiver å gjøre det) og vurderer resultatene. Som en del av dette arbeidet utformer profesjonsutøveren både et bilde/en beskrivelse av hvilken situasjon som søkes oppnådd, og et forslag til prosess for å realisere den ønskede framtidssituasjonen. Innenfor romlig planlegging er det som utformes dels en beskrivelse (ved hjelp av kart, tekst og andre illustrasjoner) av hvilken romlig fordeling av bebyggelse, aktiviteter, infrastruktur og ubebygde arealer man ønsker å oppnå innenfor et bestemt geografisk område, og dels en strategi for å gjennomføre den $\emptyset$ nskede romlige utviklingen. Den romlige utviklingen påvirkes imidlertid også av en rekke andre aktører enn planleggingsinstansen, og romlig planlegging har som regel bare indirekte innflytelse på arealbruk og utbygging (bortsett fra de byggeoppgavene der det offentlige selv står som byggherre, f. eks. skoler, sykehus, veger og jernbaner). By- og regionplanlegging skiller seg derfor fra andre designfag som $\mathrm{f}$. eks. arkitektur ved at det er nødvendig å rette like stor oppmerksomhet mot utforming av strategier for å realisere ønskelige arealbruks- og utbyggingsmønstre, som mot selve det romlige innholdet (Needham, 2000:443). Slik indirekte påvirkning kan skje ved å sette opp regler for i hvilke deler av et geografisk område det kan gis tillatelse til oppføring av bygninger med forskjellige bruksformål (med nærmere bestemmelser om bl.a. bebyggelsens tetthet, høyde og utforming i de tilfellene der bygging skal tillates), ved å prøve å påvirke andre (overordnede) myndigheter til å etablere infrastruktur i et gitt område (f. eks. nye hovedveger), eller ved at overordnete myndigheter utsteder retningslinjer som lokale planmyndigheter forutsettes å følge i sine bindende planer (Needham, 2000:ibid.:445).

Siden det er innholdet i planene som mest direkte berører romlige forhold, vil jeg først og fremst fokusere på de innholdsmessige aspektene. At by- og regionplanleggingen i det hele tatt finner det relevant å beskjeftige seg med det jeg ovenfor omtalte som de seks grunnspørsmålene, betyr at man tar for gitt at det ikke er likegyldig hvilke svar en foreslått utbygging eller arealbruk innebærer. Ulike former for arealbruk og utbygging har konsekvenser for natur og samfunn som i forskjellig grad oppfattes som positive eller negative. Noen av disse konsekvensene er direkte følger av byggearbeid, f. eks. virkninger for dyrelivet ved at et tidligere skogområde viker plass for bygninger og asfalt. Andre konsekvenser oppstår fordi utbyggingen eller arealbruksendringene fører til endringer i folks atferd. Nedbyggingen av skogområdet i eksemplet kan f. eks. føre til at beboerne i lokalsamfunnet like ved kommer sjeldnere ut i naturen og reduserer mosjonsaktiviteten. 
Eller de kan begynne å kjøre bil til et skogområde noen kilometer borte, siden den lokale skogen der de pleide å gå på tur ikke lenger eksisterer. De som flytter inn i de nye boligene i det tidligere skogområdet, får en annen og kanskje lengre reiserute til jobb, skole, butikk og i forbindelse med vennebes $\varnothing \mathrm{k}$ enn de hadde før. Kanskje går de over fra å sykle til å kjøre, siden avstandene er blitt lengre. Men noen velger kanskje å bruke nærbutikken på stedet de har flyttet til, trass i at vareutvalget her er lite. De nye kundene kan så kanskje føre til at denne butikken etter hvert ser seg i stand til å utvide varetilbudet.

Bortsett fra de rent naturmessige konsekvensene, har alle disse eksemplene på virkninger til felles at de innebærer at fysisk/romlige endringer påvirker menneskers atferd. By- og regionplanleggere forutsetter altså - eksplisitt eller implisitt - at romlige forhold kan være medvirkende årsaker til menneskers handlinger. Selv om denne forståelsen sannsynligvis er i tråd med hvordan folk flest ser på saken, er en slik oppfatning ikke ukontroversiell i akademia.

Innenfor sosiologien var det f. eks. lenge et rådende syn at de fysiske omgivelsene ikke har noen vesentlig betydning for folks handlinger (Tonboe 1993; Benton og Redclift 1994). Denne holdningen kan muligens føres tilbake til den sosiologiske klassikeren Emil Durkheim. Ifølge denne tradisjonen kan sosiale fenomener bare forklares ved å forbinde dem med andre sosiale fenomener (i motsetning til forklaringer som viser til f.eks. psykologiske, biologiske eller fysiske forhold) (Tonboe, 1993, s. 4; Lidskog, 1998, s. 22). Oppfatningen har delvis også røtter i arven fra Max Weber. Teoretikerne innenfor denne tradisjonen legger riktignok vekt på at alle menneskers atferd påvirkes av hvordan de oppfatter omgivelsene. Disse oppfatningene antas imidlertid først og fremst å bli dannet gjennom påvirkning fra de aktørene man er omgitt av, og ikke fra de fysiske omgivelsene (Lidskog, 1998, ibid.). De amerikanske sosiologene Dunlap og Catton (1983, s. 118) oppsummerer konsekvensene av den tradisjonelle sosiologiens behandling av det fysiske miljøet slik:

Arven fra Durkheim pekte mot at det fysiske miljøet burde bli ignorert, mens arven fra Weber tilsa at det kunne ignoreres, ettersom det ble ansett som uviktig for det sosiale livet. Hvis man brøt disse tradisjonene og antydet at de fysiske omgivelsene kanskje kunne være relevante for å forstå menneskelig atferd eller sosial organisering, risikerte man å bli stemplet som "miljødeterminist". (Min oversettelse.)

Sosiologiens ignorering av naturen og det romlige har fått Ted Benton (som selv er sosiolog) til å spørre seg om hvorfor sosiologer har "natur-fobi" (Benton, 2001). Men "rom-blindheten" (Tonboe, 1993) omfatter ikke bare sosiologien, den preger langt på veg også de andre samfunnsvitenskapene. En fornekting av de fysisk/romlige omgivelsenes betydning for menneskelig atferd preger også statsvitenskapen og ikke minst sosialøkonomien (Benton \& Redclift, 1994). Blant sosialøkonomene er den dominerende oppfatningen i dag at de fysiske omgivelsene overhodet ikke representerer noen grenser for veksten i produksjon, forbruk og kapitalakkumulasjon (Daly, 1993; Kovel, 2002; se også Næss, 2006). Dette har fått kritikere til å karakterisere nyklassisk økonomi som "autistisk", og basert på aksiomatiske antakelser som så å si er immune overfor kunnskapsbidrag fra andre disipliner (Fullbrook, 2004).

En avvisning av romlige forholds betydning for samfunnsforhold og menneskelig aktivitet preger merkelig nok også viktige deler av den samfunnsgeografiske tradisjonen. Ifølge Manuel Castells (1977, sitert etter Tonboe, ibid., s. 4 og 531) har rommet ikke noen betydning uavhengig av den sosiale bakgrunnen som har produsert det. Alt det rommet eventuelt måtte bety, ligger $\mathrm{i}$ de sosiale, økonomiske og politiske kreftene som har produsert det. A tillegge rommet betydning ut over dette, er ifølge Castells illegitim rom-fetisjisme. I tråd med dette avviser han å skille det romlige fra det sosiale, også når det gjøres for analytiske formål ${ }^{3}$.

Castells har selvsagt rett $\mathrm{i}$ at de bygde omgivelsene er et resultat av menneskelig handling. Men når disse bygningene og infrastrukturelle anleggene først er oppført, er de også med og danner forutsetninger for menneskers atferd. De bygde omgivelsene skaper framkommelighet og barrierer, nærhet og avstand, og de tillater eller legger til rette for noen aktiviteter på bekostning av andre. Bebyggelse og infrastruktur har også en betydelig permanens. Bygninger har ofte en levetid på 50- 
100 år eller mer, og dagens veger og annen teknisk infrastruktur i eldre bydeler følger i mange tilfeller de samme traseene som de har gjort i flere hundre år.

I motsetning til den tradisjonelle sosiologiens og deler av samfunnsgeografiens nedtoning av de fysiske omgivelsenes mulige betydning for menneskelig handling, vil nettopp denne kategorien strukturelle forutsetninger være av spesiell interesse innenfor mye av planforskningen. På den annen side har det blant enkelte arkitekter vært en tendens til å tillegge de fysiske omgivelsene en nærmest determinerende betydning for menneskelig handling (Chermayeff 1982 sitert etter Tonboe, ibid. s. 61; Hansen 1989). Det er nødvendig å avgrense seg både fra en slik "romfetisjisme" og fra den "romblindheten" som har dominert sosiologisk teori.

Mye av fagdebatten blant planleggere og planforskere har imidlertid vært preget av lav bevissthet om vitenskapsfilosofiske og meta-teoretiske forhold. Planleggingsfagets forståelse av rommets betydning har stort sett vært implisitt, ikke eksplisitt. Det har vært liten refleksjon omkring metateori og begreper. By- og regionplanleggernes tradisjonelle fokus på planenes innhold (altså på de romlige forholdene og deres konsekvenser) måtte i 1980- og 1990-årene vike for et økt fokus på planleggingsprosessen. Det ble vanlig å snakke om en kommunikativ vending (Healey, 1996) i planleggingsteori og planpraksis. En rekke ulike årsaker har sannsynligvis vært medvirkende til denne utviklingen, både et oppgjør med en positivistisk inspirert fysisk determinisme, en kritikk av teknokratisk planlegging uten innpass for alminnelige menneskers perspektiver, og en mer overordnet liberal strømning i politikken der prosesslikhet og desentralisert innflytelse ble sett på som viktigere enn resultatlikhet. Men fortrengningen av innhold til fordel for prosess henger sannsynligvis også sammen med at nye faggrupper gjorde sitt inntog blant planleggerne fra 1970årene og framover. Mens plankontorene tidligere først og fremst var befolket av arkitekter og ingeniører, fikk disse fagfolkene etter hvert selskap av økonomer, samfunnsgeografer, sosiologer og statsvitere. Disse gruppene aksepterte ikke ukritisk den fagforståelsen som til da hadde rådd grunnen. De brakte med seg sine egne fagtradisjoner og godtok ikke uten videre de tradisjonelle byplanleggernes ideer om nabolaget som utgangspunkt for sosiale kontaktnett, senterhierarkier, rasjonelle utbyggingsprinsipper - eller allmenngyldige estetiske kvaliteter. Tvert imot ble slike forestillinger kritisert for å bygge på en naiv fysisk determinisme som ikke tok hensyn til aktørenes ulike ressurser, verdier, preferanser og forpliktelser. Særlig i den akademiske planleggingsdebatten var troen på at det er ønskelig og mulig for det offentlige å påvirke byutviklingens romlige innhold, på vikende front. Noe av kritikken mot de tradisjonelle byplanlegger-forestillingene var også klart berettiget. Arkitektenes hardnakkede tro på at man ved å bringe arbeidsplasser ut i forstedene "der folk bor" kunne redusere pendlingen, var f. eks. basert på en overdreven tro på betydningen av geografisk nærhet ved valg av arbeidssted.

Den reduserte interessen for arealplanleggingens innhold førte imidlertid også til at utbyggere og koalisjoner av innflytelsesrike interesseparter møtte mindre faglig motstand fra planleggerne enn de ellers ville ha gjort. Antakelig var dette med på å føre til en mer markedsbasert romlig utvikling av byer og tettsteder (se f. eks. Fainstein \& Fainstein, 1996 og Purcell, 2008) - med negative konsekvenser for natur og miljø og ikke minst med stor avhengighet av bilbruk.

Planleggingspraksisen endret seg likevel tregere enn skiftningene $i$ den planleggingsteoretiske debatten. Og fra slutten av 1980-årene bidro Brundtlandkommisjonens rapport (WCED, 1987) og diskusjonen om bærekraftig utvikling til en fornyet interesse for konsekvensene av den romlige byutviklingen. Etter hvert skjedde det også en opptrapping av forskningen omkring slike konsekvenser, ${ }^{4}$ og by- og regionplanleggerne kunne ikke lenger - vil jeg hevde - med like god grunn kritiseres for naivitet i forhold til sammenhengene mellom romlige strukturer og menneskelig atferd.

Som jeg nevnte tidligere, er de romlige forholdenes kausale status i forhold til menneskers handling (samt innvirkningen på trivsel og oppfatninger) langt på veg en forutsetning for at det i det hele tatt er noe poeng $\mathrm{i}$ å drive med by- og regionplanlegging. Hvis romlige forhold ikke hadde noen innflytelse på handlinger, trivsel, etc, ville det ikke være noen grunn til at det offentlige skulle fors $\varnothing \mathrm{ke}$ å påvirke den romlige utviklingen av byer og regioner. (Og det ville heller ikke være noen grunn for private aktører til å engasjere seg - verken som utbyggere, eiendomsmeglere eller kunder 
på eiendoms- og boligmarkedet!) Den betydelige interessen offentlige og private aktører retter mot byers og regioners romlige utvikling er en klar pekepinn om at de romlige forholdene har betydning for handlingsmønstre, velferd og økonomi, og at antakelsene i visse samfunnsvitenskaper om at alt det rommet eventuelt måtte bety, ligger i de sosiale, økonomiske og politiske kreftene som har ${\text { produsert } \operatorname{det}^{5} \text {, mangler seriøsitet }}^{6}$.

Kanskje var det som en reaksjon på den kvantitative geografiens og "sosialfysikkens" (Brown, 1995) forestillinger om at menneskers handlinger i stor grad lar seg forutsi ut fra romlige parametre, at man gikk til den motsatte ytterligheten og frakjente de fysiske og romlige forholdene noen betydning for samfunnsforhold og menneskers aktivitet. En teori som har hatt stor betydning i by- og regionplanleggingen bl.a. som hjelp til å lokalisere ulike typer av offentlig servicefunksjoner som i ulik grad er spesialiserte, er Christallers sentralstedsteori (1933/1966). Denne teorien tar utgangspunkt $\mathrm{i}$ at størrelsen på det kundegrunnlaget eller antall potensielle brukere som detaljhandel og tjenesteytende funksjoner er avhengig av for å kunne drives lønnsomt, varierer mellom forskjellige typer av tjenester og varekategorier. En allment praktiserende lege behøver $\mathrm{f}$. eks. ikke like stort befolkningsunderlag som en hjernekirurg, fordi den andelen av befolkningen som blir behandlet av allment praktiserende leger i løpet av et år, er langt høyere enn den andelen som får foretatt hjerneoperasjon. På tilsvarende måte kan en dagligvarebutikk overleve med et lavere befolkningsgrunnlag enn f. eks. en butikk som selger musikkinstrumenter. Funksjoner som handel, helsetjenester, undervisning, kulturell aktivitet, underholdningsaktivitet osv. kan derfor gradueres etter størrelsen på det geografiske området funksjonen vanligvis dekker. Funksjonenes forskjellige omlandsstørrelser gir på denne måten, ifølge sentralstedsteorien, grunnlag for at det utvikles et hierarki av sentre.

Kritikere har hevdet at sentralstedsteorien bygger på positivistiske prinsipper som forutsetter at det finnes en identifiserbar orden $\mathrm{i}$ den materielle verden, at mennesker er rasjonelle, nyttemaksimerende beslutningstakere, og at $\varnothing$ konomisk aktivitet finner sted i en kontekst av fri konkurranse og søking etter likevekt (Brown, ibid.). Faktiske bymønstre avviker da også ofte betydelig fra dem som sentralstedsteorien forutsier (noe Christaller også gjorde leserne oppmerksom på, siden det eksisterer en rekke lokaliseringsfaktorer i tillegg til dem som inngikk i modellen hans: byer lokaliseres f. eks. som regel ikke på fjelltopper, selv om avstanden til øvrige sentre isolert sett skulle tilsi at byen burde ligge nettopp der.)

Til tross for den omfattende kritikken som sentralstedsteorien særlig i 1970- og 1980-årene var utsatt for, er den i dag bredt akseptert som en delvis forklaring på senterdannelser (Sayer, 1992:217; Brown, 1995). Selv om mennesker ikke bare er rasjonelle, nyttemaksimerende beslutningstakere, betyr ikke dette at de slett ikke bruker instrumentell rasjonalitet. Ifølge Sayer (ibid.) gir sentralstedsteorien et viktig bidrag til å forstå de mekanismene som påvirker lokaliseringen av senterfunksjoner. Teoriens styrke ligger således i det bidraget den gir til forklaring, mens dens evne til å forutsi det faktiske lokaliseringsmønstret i et gitt område er begrenset (Sayer, ibid.). I en konkret situasjon vil man likevel ved å kombinere teorien med kontekstuell kunnskap sannsynligvis kunne si noe mer velbegrunnet om hvilke funksjoner det vil være økonomisk grunnlag for å lokalisere innenfor forskjellige deler av et område - og dermed også om hvilke lokaliseringsmønstre som sannsynligvis vil oppstå - enn hvis man ikke hadde noen sentralstedsteori. Teoriens betydning i praktisk by- og regionplanlegging bygger på en slik tolkning, der det anerkjennes at geometriske avstander og ulike funksjoners typiske krav til befolkningsunderlag bare utgjør ett av flere sett med faktorer som bør tas i betraktning ved planlegging av hvor ulike sentrumsfunksjoner bør ligge.

En annen teori som har vært skyteskive for en liknende kritikk, men som har gitt et viktig bidrag til by- og regionplanleggeres forståelse av hvordan lokaliseringsmønstre og mobilitetsressurser legger begrensninger og åpner muligheter for folks deltakelse i aktiviteter, er Torsten Hägerstrands (1970) tidsgeografi.

Ifølge Benton og Redclift bygger den avvisningen av romlige forholds betydning for mennesker og samfunn som har vært utbredt blant sosiologer og andre samfunnsvitere, i seg selv på en slags positivisme, med dens syn på vitenskaplig kunnskap som et deduktivt hierarki av abstrakte 
lover. Sett fra mitt ståsted bygger den også - ved å avvise at romlige strukturer har kausal innvirkning på menneskers handlinger - på en feilaktig oppfatning av forholdet mellom strukturer og aktører.

Forholdet mellom strukturer og aktører er et av de mest omstridte spørsmålene i samfunnsteorien. Ifølge Archer (2000:6) ser en tradisjon som særlig er utbredt blant økonomer, på samfunnsstrukturer som ikke noe annet enn uttrykk for individuelle, instrumentelt rasjonelle aktørers preferanser. En motsatt posisjon, representert ved visse diskursteoretikere så vel som deler av den kapitallogiske tradisjonen, betrakter alle menneskelige egenskaper (bortsett fra vår biologiske konstitusjon) som samfunnsskapte. En tredje posisjon, bl.a. representert ved Giddens' (1984) strukturasjonsteori, hevder at strukturer og aktører er gjensidig konstituerende og ikke kan holdes fra hverandre. Det blir dermed heller ikke mulig å analysere hvordan strukturer og aktører påvirker hverandre, siden verken strukturenes eller aktørenes særskilte egenskaper og påvirkningskrefter kan identifiseres.

I motsetning til disse tre posisjoner bygger by- og regionplanleggingen - som oftest implisitt og uten særlig mye refleksjon - på en antakelse om at både strukturer og aktører har særskilte egenskaper og kausale krefter. Bortsett fra de naturgitte forutsetningene, er de strukturene som omgir oss, på forskjellige måter "sosialt konstruerte". Det konstruerte kan være fysiske objekter, $f$. eks. bygninger eller veier, eller mer immaterielle strukturer som $\mathrm{f}$. eks. eiendomsforholdene og de $\emptyset$ konomiske betingelsene, eller rådende oppfatninger og kulturelle tradisjoner. Når de forskjellige former for strukturer først er blitt skapt, har de kausale krefter og egenskaper som er forskjellige fra og virker ut over summen av de aktørkreftene som forårsaket strukturenes tilblivelse. Selv om menneskeskapte fysiske strukturer, samfunnets politiske konstitusjon, det rådende økonomiske system og andre relativt stabile egenskaper ved samfunnet vårt er sosialt konstruerte og resultater av diskurser, kan de i en gitt situasjon og for visse analyseformål betraktes som "ekstradiskursive" strukturer. Dette vil f. eks. være tilfellet hvis de diskursene som i sin tid produserte strukturene, ligger langt forut $\mathrm{i}$ tid for de sosiale handlingene vi ønsker å forklare. Videre er de individene som strukturene påvirker, ikke nødvendigvis de samme som de som konstruerte disse strukturene.

Som vist i figur 1, hentet fra Bhaskar (1998): selv om strukturer blir skapt av aktørers handlinger, inngår de som betingelser for framtidige handlinger, ofte lenge etter at de menneskene som i sin tid skapte strukturene, er døde. Samtidig blir strukturene modifisert og forandret av menneskers handlinger, oftest gradvis og langsomt, men noen ganger mer dramatisk og hurtig.

Ikke minst framstår det som ytterst rimelig å anta at de materielle strukturene har innvirkning på menneskers handlinger. Disse strukturene (f. eks. veier og bygninger) har en større bestandighet enn de fleste andre sosiale strukturer. I enda større grad gjelder det de naturgitte forutsetningene (terrengforhold, klima, vassdrag, vegetasjon, m.m.).

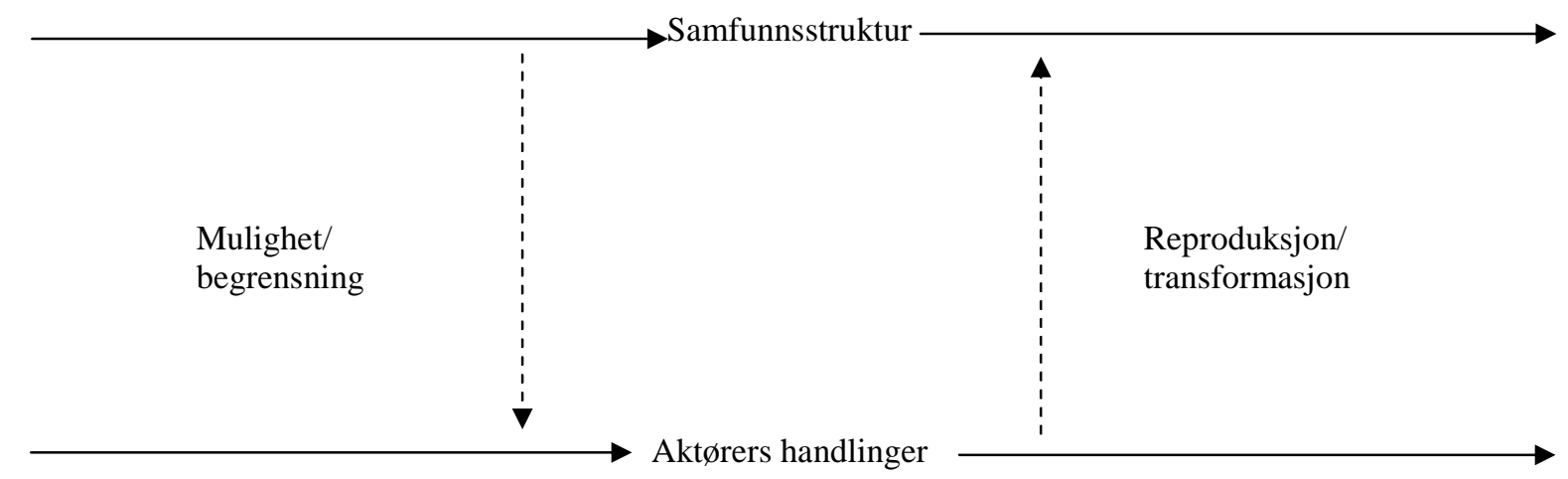

Figur 1: Samfunnsstruktur og aktørers handliner ifølge den kritiske realismens transformasjonsmodell. Kilde: Bhaskar (1998: 36)

De fysiske/romlige omgivelsene utgjør et sett med rammebetingelser som bidrar til å gjøre noen 
typer handlinger mulige og andre umulige. Innenfor spennet av mulige handlinger gjør de romlige omgivelsene dessuten visse former for atferdsmessige tilpasninger mer sannsynlige enn andre, $\mathrm{f}$. eks. fordi forskjeller i geografisk nærhet gjør noen valg mer tidkrevende, kostbare eller ubekvemme enn andre. De bygde omgivelsene skaper tilgjengelighet og barrierer, nærhet og avstand, og de tilrettelegger for noen aktiviteter på bekostning av andre. (Se Næss, 2004 for en mer utdypende drøfting, med boliglokaliseringens innvirkning på beboernes transportaktivitet som eksempel.)

Samtidig er det opplagt at by- og regionplanleggingen ikke bygger på en strukturdeterministisk oppfatning. Aktører påvirker strukturene, enten gjennom å vedlikeholde og reprodusere dem, eller ved endring. Hele poenget med by- og regionplanleggingen er jo å påvirke den transformasjonen av de romlige strukturene som en rekke prosesser i samfunnet gir opphav til. I noen tilfeller - kanskje de fleste - dreier planleggingen seg om å skape rammer for byggevirksomhet og arealbruksendringer som ulike private aktører tar initiativ til (jf. omtalen foran av romlig planlegging som designfag). Men i noen tilfeller (offentlige bygg, infrastruktur) er det offentlige selv initiativtaker og byggherre, og transformasjonen av romlige forhold gjennom planlegging får $\mathrm{i}$ slike situasjoner en langt mer proaktiv karakter.

Denne oppfatningen - at rommet påvirker oss, men at vi også selv er med på å endre de romlige forholdene - støttes også av sosiologen Dag Østerberg. Han er en av de få sosiologene som har interessert seg for det romlige, bl.a. i boken "Arkitektur og sosiologi i Oslo" (1998). I et intervju i 2002 oppsummerte han sitt syn på forholdet mellom det romlige og det sosiale slik: "Som mennesker er vi med på å forme våre materielle omgivelser gjennom planlegging og arkitektur. Men de materielle strukturer virker igjen tilbake på oss og former våre liv." (Østerberg, 2002).

Det er imidlertid viktig å være oppmerksom på tidsfaseforskjellen her. Vi fødes inn i en romlig kontekst som allerede eksisterer, så selv om vi har mulighet til å endre de romlig-strukturelle forholdene, er vi likevel i enhver konkret handlingssituasjon undergitt de muligheter og begrensninger som den konkrete romlig-strukturelle konteksten utgjør. Denne faseforskjellen mellom omgivelsenes påvirkning på våre handlinger og våre handlingers påvirkning av omgivelsene er også et hovedpoeng i den kritiske realismens transformasjonsmodell (jf. figur 1), noe som skiller denne modellen fra Giddens' strukturasjonsteori.

Foran har vi først og fremst snakket om rommet som noe som muliggjør, letter, vanskeliggjør eller hindrer ulike typer menneskelig aktivitet. Det har med andre ord dreid seg om rommets praktisk tilretteleggende eller begrensende funksjon $\mathrm{i}$ forhold til handlinger med et instrumentelt sikte. Men rommet kan også påvirke gjennom symbolske og estetiske uttrykk. Slik påvirkning kan noen ganger være direkte (f. eks. når et hagegjerde med port utenfor en enebolig riktignok ikke fysisk hindrer folk adgang, men likevel signaliserer at dette er privat eiendom på en så tydelig måte at de færreste uvedkommende vil gå inn i hagen). Påvirkningen kan også være indirekte gjennom våre oppfatninger av hvilke institusjoner, befolkningsgrupper og individer som har makt og status. Når besøkende til Riksdagen i Helsinki må forsere en lang trapp med trinn som strekker seg i hele fasadens lengde for å komme fra torget nedenfor bygningen til inngangen, har dette kanskje noe med maktsymbolikk å gjøre? (Som besøkende må man bokstavelig talt se opp til den høyereliggende bygningen, det å nærme seg den krever fysisk anstrengelse, og man er liten sammenliknet med de opphøyde og overdimensjonerte søylene og inngangsdørene.) Utformingen av rom kan også appellere til estetisk smak hos ulike befolkningsgrupper, og dermed dels gjøre den visuelle persepsjonen mer eller mindre behagelig og inspirerende, og dels bidra til identifikasjon og bekreftelse på gruppetilhørighet blant befolkningsgrupper som deler de sammen estetiske kodene.

Disse siste poengene illustrerer også at arkitekter og byformere ${ }^{7}$ ofte vil legge hovedvekt på andre aspekter av det romlige enn f. eks. geografer eller byplanleggere som er opptatt av sammenhenger mellom arealbruk og transport. De sistnevnte vil bl.a. være opptatt av senterstrukturer, kommunikasjonsårer og avstandsfriksjon. Planleggere som arbeider med friluftsliv og naturvern vil på sin side være opptatt av vegetasjon, dyreliv, økosystemer, naturlig topografi og variasjon i landskapstyper. Og planleggere som er opptatt av å begrense energibruken i bygninger (hvis det ennå finnes noen slike) vil være opptatt av terrengformasjoner/sol/skygge, le, vindforhold osv. 
Det er selvsagt også snakk om forskjeller i hvilken geografisk skala oppmerksomheten rettes mot. Hustegnende arkitekter, byformere og landskapsarkitekter har hver sine typiske målestokker å operere i. Noen byplanleggere vil typisk være opptatt av byen og byregionen som nivå, mens andre er mest interessert i utformingen av det enkelte nabolag eller lokalområde.

Forskjellene i hvilken skala og hvilke romlige egenskaper det fokuseres på har noen koplinger til ulike rombegreper som har vært mye diskutert blant teoretikere og filosofer: absolutt rom, relativt rom og relasjonelt rom. Det absolutte rom er den klassiske regionalgeografiens begrep. Rommet ses her som en ting i seg selv, det er en "passiv arena" som tingene skjer innenfor (Simonsen, 1999:6). Landskapsarkitekters og byformeres fokus på de visuelle kvalitetene i et avgrenset område kan vel sies å være koplet først og fremst til et slikt rombegrep. Det relative rombegrepet fokuserer på rommet som forhold mellom objekter, der rommet bare eksisterer fordi objektene står i et fysisk forhold til hverandre (Simonsen, ibid.). Det "grunnspørsmålet" i den fysiske planleggingen som handler om hvordan ulike funksjoner bør lokaliseres $\mathrm{i}$ forhold til hverandre, tar opplagt utgangspunkt i et slikt rombegrep. Det relasjonelle rombegrepet ser rommet som noe som finnes $i$ objektene, dvs. at et objekt bare eksisterer hvis det selv inneholder og representerer relasjoner til andre objekter. Ifølge Simonsen (ibid.:7) er implikasjonen av dette for det første at rommet underordnes samfunnsmessige prosesser, og for det andre at rom og objekt smelter sammen - det ene kan ikke eksistere atskilt fra det andre. Som nevnt foran er denne oppfatningen temmelig problematisk hvis den gjør krav på å være allmenngyldig, jf. kritikken min ovenfor av Castells avvisning av rommet eller det fysiske som en separat analytisk kategori. Men samtidig er den for visse problemstillinger opplagt relevant. Særlig gjelder dette for analyser av samfunnsmessige drivkrefter bak byutviklingen, og herunder muligheten for å gripe inn i disse prosessene gjennom offentlig planlegging.

I den filosofiske og teoretiske debatten omkring rombegrepet er det absolutte, det relative og det relasjonelle rommet ofte blitt framstilt som konkurrerende og gjensidig utelukkende perspektiver. En slik enten-eller-holdning er uheldig. Verden består av mange ulike årsakskrefter som opererer på samme tid, og disse fanges som regel ikke opp innenfor en enkelt disiplin eller forskningstradisjon. Jeg må derfor si meg enig med Kirsten Simonsen når hun skriver:

Man kan mene at det med denne skisserte utviklingen av faget [fra et absolutt via et relativt til et relasjonelt rombegrep, min tilføyelse] ble kastet noen barn ut med badevannet, og at rommet $i$ en del sammenhenger kan eksistere som absolutt, relativt og relasjonelt rom på en gang. ... Debatten hvilte i utgangspunkt på en dikotomisering av tidligere standpunkter. ... En del av forklaringen på denne dikotomiseringen ligger sannsynligvis $i$ at den nymarxistiske forskningen - trass $i$ proklamerte utgangspunkter i dialektisk materialisme - hadde vanskelig for å frigjøre seg fra positivismens endimensjonale tilnærming til kausalitetsforhold. ... Det fører analysen av rommets samfunnsmessige rolle inn i det som Lindstrøm (1986) karakteriserer som en blindgate der man blir tvunget til å ta stilling til rommet som noe som enten er en determinerende eller en determinert sosial faktor (Simonsen 1999:7-8, min oversettelse).

I kontrast til en slikt endimensjonal forståelse av kausalitetsforhold er en multikausal virkelighetsoppfatning slik bl.a. Bhaskar (1998) og Sayer (1992) gir uttrykk for, mer fruktbar. Det geografiske rommet er ikke et lukket system der objekter påvirkes av bare en enkelt årsaksfaktor. Tvert imot er det et åpent system der mange ulike årsaksfaktorer er til stede samtidig. Noen av disse forsterker hverandre, andre motvirker hverandre, og noen aktiveres bare under påvirkning fra andre årsaksfaktorer. En slik oppfatning ligger også i stor grad som en implisitt forståelse blant by- og regionplanleggere. Denne avspeiler by- og regionplanleggingens karakter som et problemorientert praksis- og forskningsfelt som er avhengig av å ta i bruk og syntetisere kunnskap fra mange ulike disipliner (Næss \& Saglie, 2000). Profesjonsutøvere og forskere på dette feltet vil derfor vanligvis ikke finne seg godt til rette innenfor enkeltstående disipliners forståelsesramme og begrepsapparat, som ofte vil være for snevert i forhold til de mange ulike årsaksfaktorene og virkningene vi har å gjøre med når det gjelder byers og regioners utvikling.

Rombegrepet finnes imidlertid ikke bare i variantene absolutt, relativt og relasjonelt rom. 
Innenfor humanistisk geografi har man vært opptatt av stedet (place) i betydningen det opplevde rom. Tuans (1979) stedsbegrep fokuserer dels på et steds iboende karakter, dels på den tilknytningen mennesker og samfunn har til et bestemt sted gjennom erfaring og minner. Arkitekturteoretikeren Christian Norberg-Schulz har gjennom begreper som stedsidentitet, stedskarakter og steds-tap vært opptatt av det samme, ut fra et fenomenologisk perspektiv (NorbergSchulz, 1980; se også Vagstein, 1999 og Lauvland, 2007). Disse emosjonelle og kulturelle aspektene ved steder fanges ikke opp av verken det relasjonelle eller det relative rombegrepet (men kan kanskje rommes innenfor et absolutt rombegrep?). De er imidlertid viktige i en planlegging som $\emptyset$ nsker å bryte ut av funksjonalismens reduksjonistiske menneskesyn, der f. eks. det å bo ble oppfattet som noe som bare dreide seg om lys, luft, friarealer og tilgjengelighet til arbeidsplasser og service. Stedets ånd (genius loci) er et uttrykk som illustrerer de fenomenologiske arkitekturteorienes orientering mot å komme fram til en holistisk forståelse av hvordan stemningen på et sted påvirkes av fysiske forhold, menneskenes aktiviteter, kultur og historie.

I by- og regionplanlegging har såkalte stedsanalyser, inspirert av place-begrepet, kommet inn som et planleggingsverktøy de siste 10-15 årene. Mens de første generasjonene av slike analyser la mye av vekten på visuelle og estetiske forhold, er sosiokulturelle stedsanalyser (se f. eks. Ruud et al., 2007) kommet som et nytt tilskudd i det millenniet vi nå befinner oss i. Viktige begreper i slike analyser er stedsbruk, stedsbilder og stedsinteresser. Stedsbruk dreier seg om praksis - hvilke formål stedet eller bestemte deler av det brukes til, hvilke måter ulike grupper bruker stedet på, og hvilken betydning man ut fra denne bruken kan tillegge de ulike områdene. Stedsinteresser har med maktrelasjoner å gjøre, og viser til ulike aktørers interesser f. eks. når det gjelder fysisk utforming, estetikk, transport, rekreasjon, kulturliv og handel, og i spørsmål om bevaring eller endring. Stedsbilder er forestillinger om og representasjoner av stedet. En sosiokulturell stedsanalyse vil her legge vekt på å identifisere hvilke ulike oppfatninger som eksisterer om stedets særtrekk, kvaliteter, mangler, ulemper, muligheter og forutsetninger, hvilke forestillinger som dominerer og hvilke som kommer lite fram eller undertrykkes (Ruud et al., 2007). De sosiokulturelle stedsanalysene tar i stor grad utgangspunkt i et rombegrep som ser rommet som sosialt konstruert. Det gjelder både den praktiske bruken, hvilke interesser som dominerer, og ikke minst hvilke forestillinger som eksisterer om et sted. Konkurrerende stedsbilder, stedsbruk og stedsinteresser utgjør ulike meningsfellesskap eller diskurser, der noen diskurser er dominerende mens andre har vanskeligere for å bli anerkjent. Den stedsidentiteten som dannes, vil preges av disse diskursene. Hvis en diskurs som i dag er marginalisert, vinner tilslutning, kan stedet bli preget av andre praksiser, prioriterte interesser og forestillinger, også om det ikke skjer store fysiske endringer i omgivelsene. Dette sosialkonstruktivistiske perspektivet behøver imidlertid ikke å innebære en fornekting av andre perspektiver, f. eks. absolutt, relativt eller relasjonelt rom.

En teoretiker som Manuel Castells, som i sine arbeider på 1980-tallet gikk inn for å viske ut distinksjonen mellom det romlige og det sosiale, har i de siste ti årene vært opptatt av lokale steder (spaces of place) som en motsats til kommunikasjonsårene og knutepunktene i de globale nettverkene (spaces of flow) (Castells, 2000). Med utviklingen mot stadig mer multikulturelle samfunn i europeiske storbyer har spørsmål omkring romlig segregasjon, integrasjon eller assimilering av etniske og kulturelle minoritetsgrupper blitt et politisk stridstema som også har påvirket dagsordenen blant byplanleggere. "Place and politics of identity" og "Urban planning and cultural identity" er titler på to bøker som for tiden leses og debatteres blant planleggerakademikere. I den grad planleggere i det hele tatt er i stand til å gripe inn i prosessene der sosiale og kulturelle gruppers identitetsoppfatning dannes og knyttes til steder, er det opplagt snakk om virkemidler ut over den tradisjonelle fysiske planleggingens regulering av arealbruk og bebyggelsens utforming. Planlegging som fokuserer på stedsidentitet og sosial identitet fokuserer snarere på kommunikative prosesser som kan skape oppslutning omkring en bestemt "visjon" for et lokalsamfunn.

En slik innretning av planleggingen mot å etablere konsensus om visjoner er for øvrig ikke noe som bare skjer i forbindelse med utfordringene det multikulturelle samfunnet stiller oss overfor. Det kan også dreie seg om å undersøke bredt hvordan ulike befolkningsgrupper (f. eks. ungdom, eldre, de som bor i et område, de som har arbeidsplassen sin der, næringslivet, politikere og 
profesjonelle planleggere) oppfatter et sted og de utviklingsmulighetene stedet har.

Utvikling av "visjoner" er også framtredende i de planene som byer og regioner lager som ledd i "stedsmarkedsføring" (branding) for å stå best mulig rustet i konkurransen om investeringer og ressurssterke arbeidstakere i en globalisert økonomi. Her dreier det seg om å skape en fortelling om stedet som kan skape ny optimisme, styrke entreprenørånden og gi et bilde utad som styrker byens eller regionens omdømme (mens man underforstått håper at andre, konkurrerende steder ikke lykkes like godt i å framstille sine lokaliteter som attraktive investerings- og tilflyttingssteder). Tiden vil vise $\mathrm{i}$ hvilken grad denne nyliberale dagsordenen vil føre til en varig endring av by- og regionplanleggingens fokus vekk fra den tradisjonelle oppmerksomheten omkring styring av arealbruk og utbygging.

\section{Konkluderende betraktninger}

Temaet for denne artikkelen er "planleggingens rombegrep". Men som det framgår foran, er det misvisende å snakke om ett enkelt rombegrep i planleggingen. By- og regionplanleggere opererer oftest underforstått - ut fra forståelser av rommet som absolutt, relativt, relasjonelt så vel som sosialt konstruert. I motsetning til enkelte akademikere med dype røtter innenfor en bestemt disiplin, ser de fleste planleggere og planforskere ikke ut til å se noen problemer i å veksle mellom å legge disse ulike rombegrepene til grunn. ${ }^{8}$ Noen vil kanskje si at dette vitner om en grunn teoretisk forståelse eller holdningsløs pragmatisme. Jeg ser det i stedet som et sunnhetstegn. Virkeligheten er atskillig mer mangefasettert enn de teoretiske brilleglassene en enkelt disiplin - eller en tradisjon innenfor en disiplin - gjør bruk av. Derfor kan man heller ikke vente at monodisiplinære begreper og teorier gjør en i stand til å forstå mer enn utvalgte deler av virkeligheten. Dette er akseptabelt så lenge man ikke inntar en imperialistisk holdning og vil "gjøre alle andre til disipler" under sine egne begreper, mens man aggressivt polemiserer mot "hedningenes" begreper. Men dessverre er det nettopp en slik korsfarermentalitet som har preget mye av begrepsdiskusjonen i samfunnsfagene. Det samme gjelder i stor grad de metateoretiske og vitenskapsfilosofiske debattene som teoretiseringen innenfor de enkelte fagene er forbundet med.

By- og regionplanlegging er et praktisk orientert fag og de teoriene planleggerne bringer inn blir til stadighet konfrontert med innspill fra andre aktørgrupper, beslutninger som må tas, utbygging og arealbruksendringer som fører til konkrete forandringer i landskapet, i folks handlingsmønstre, oppfatninger og erfaringer med hvordan de planlagte omgivelsene faktisk utviklet seg. Det er ikke urimelig å tenke seg at denne kontakten med "det virkelige liv" fungerer som en slags "vaksine" mot å grave seg for dypt ned i monodisiplinære brønner der man bare har utsikt til en flik av verden utenfor. Metateoretiske perspektiver som f. eks. positivisme, empirisisme, nykantianisme og radikal sosialkonstruktivisme er blitt kritisert for å neglisjere og ekskludere viktige deler av virkeligheten (Bhaskar \& Danermark, 2006), og for å insistere på standpunkter som i praksis ville gjøre det umulig å frambringe viten om mangefasetterte og komplekse fenomener som $\mathrm{f}$. eks. byutvikling og konsekvenser av denne. Innenfor et positivistisk paradigme vil f. eks. kunnskap basert på observasjoner som ikke lar seg kvantifisere og behandle matematisk, bli sett på som mindre solid og kanskje bli avvist som rent subjektive meninger. De egenskapene ved rommet som fanges opp gjennom begrepene opplevd rom, relasjonelt rom og sosialt konstruert rom lar seg vanskelig innpasse $i$ et slikt paradigme. På den annen side innebærer en radikal sosialkonstruktivistisk posisjon en utvisking av forskjellen mellom sosiale objekters eksistens og de deltakende aktørenes oppfatning og forståelse av disse objektene. Romlige egenskaper som fanges opp gjennom det relative rombegrepet, f. eks. geometrisk målte avstander og høydeforhold, vil da lett bli sett på som uinteressante, mens fokus i stedet rettes mot hva som kulturelt oppfattes som nære og fjerne steder. ${ }^{9}$

Heldigvis opererer by- og regionplanleggere sjelden innenfor slike ontologiske tvangstrøyer. (At dette ofte skyldes manglende teoretisk fordypning er en annen ting - en høyning av det metateoretiske refleksjonsnivået blant planleggere så vel som planforskere ville avgjort være en fordel!) Problemstillingene og utfordringene som by- og regionplanleggere fors $\varnothing$ ker å hanskes med, går på tvers av grensene mellom ulike disipliner, og planleggerne må derfor benytte teorier og 
begreper fra ulike felt for å forstå de situasjonene de arbeider med. Derfor har de også bruk for å kombinere ulike rombegreper.

Takk til følgende personer som har kommentert tidligere versjoner av artikkelen: Karl Georg Høyer, øvrige deltakere i Storbyprogrammets romseminar 29.4.08 ved Høgskolen i Oslo, Ole B. Jensen, og de to anonyme fagfellene som har vurdert artikkelen for FORMakademisk.

\section{Petter Næss}

Professor, dr.ing.,siv. arkitekt

Institut for Samfundsudvikling og planlægning ved Universitetet i Aalborg/ Prof. II Storbyprogrammet ved Høgskolen i Oslo/ Bistilling ved Transportøkonomisk institutt.

Email adresse: petter.nass@hio.no / petter@plan.aau.dk

\section{Referanser}

Archer, M. S. (2000): Being Human. The Problem of Agency. Cambridge: Cambridge University Press.

Benton, T. \& Redclift, M. (1994): "Introduction." I: Redclift, M. \& Benton, T. (red.): Social Theory and the Global Environment. London: Routledge

Benton, T. (2001): 'Why are sociologists naturephobes?' I Lopez, J. \& Potter, G. (red.): After Postmodernism: An Introduction to Critical Realism, s. 132-145. London/New York: The Athlone Press.

Bhaskar, R. \& Danermark, B. (2006): "Metatheory, interdisciplinarity and disability research-a critical realist perspective." Scandinavian Journal of Disability Research, Vol. 8, s. 278-97.

Bhaskar, R. (1998): The Possibility of Naturalism: A Philosophical Critique of the Contemporary Human Sciences. Third Edition. London/New York: Routledge.

Brown, S. (1995): "Christaller knew my father: Recycling central place theory." Journal of Macromarketing, Spring 1995, s. 60-72.

Castells, M. (1977): The Urban Question: a Marxist Approach. London: Arnold.

Castells, M. (2000): The rise of the network society. Oxford : Blackwell

Chermayeff, S. (1982): Selected Writings 1930-1980. Redigert av R. Plunz. Cambridge, Massachusetts: The M.I.T. Press.

Christaller, W. (1933/1966): Central Places in Southern Germany. Englewood Cliffs, NJ: Prentice-Hall, 1966. (Oversettelse av "Die Zentralen Orte in Süddeutschland", publisert i 1933.)

Daly, H. E. (1993) Sustainable Growth: An Impossibility Theorem. I Daly, H. E. \& Townsend, K. N. (red.) Valuing the Earth. Economics, Ecology, Ethics, pp. 267-273 (Cambridge, MIT).

Danermark, B., Ekström, M., Jacobsen, L. \& Karlsson, J. C. (2001): Explaining Society. Critical realism in the social sciences. London/New York: Routledge.

Dunlap, R. E. \& Catton, W. R. jr. (1983): "What environmental sociologists have in common (whether concerned with "built" or "natural" environments)." Sociological Inquiry, Vol. 53, s. 113-135.

Fainstein, S. and Fainstein, N. (1996): "City Planning and Political Values: An Updated View." I Campbell, S. and Fainstein, S. (red.): Readings in Planning Theory, s. 265-287. Malden, Mass./Oxford: Blackwell.

Fogelsong, R.E. (1996): "Planning the Capitalist City." I Campbell, S. and Fainstein, S. (red.): Readings in Planning Theory, s. 169-175. Malden, Mass./Oxford: Blackwell.

Fullbrook, E. (2004): "Broadband versus Narrowband Economics." Introduksjonskapittel i Fullbrook, E. (red.) A Guide to What's Wrong With Economics (London, Anthem Press).

Giddens, A. (1984): The Constitution of Society. Outline of the Theory of Structuration. Cambridge: Polity Press.

Hansen, T. (1989): "Byplanlegging og planleggerroller." Norsk statsvitenskapelig tidsskrift (5), nr. 1, s. 67-88.

Healey, P. (1996): "Planning through debate. The communicative turn in planning theory." I Campbell, S. \& Fainstain, S. (red.): Readings in Planning Theory, s. 234-257. Cambridge, Mass./Oxford: Blackwell.

Hägerstrand, T. (1970): Urbaniseringen af Sverige - en geografisk samhällsanalys. Appendix 4 til SOU $1970: 14$. Stockholm.

Høyer, K. G. (2008): Indikatorer og Analyseverktøy i miljфpolitikk og -planlegging. Forelesning ved UMB-Ås/ILP, 13. mars 2008.

Høyer, K. G. \& Næss, P. (2001): "The Ecological Traces of Growth.” Journal of Environmental Policy and Planning, Vol. 3, 2001, s. 177-192.

Høyer, K. G. \& Næss, P. (2008): "Interdisciplinarity, Ecology and Scientific Theory - The Case of Sustainable Urban Development." Publiseres i Journal of Critical Realism, Vol. 7, no. 2, 2008.

Klosterman, R. (1985): "Arguments for and against planning." Town Planning Review Vol. 56, s. 5-20.

Kovel, J. (2002): The Enemy of Nature: The end of capitalism or the end of the world? New York: Zed Books.

Langdalen, E. (1993): Arealplanlegging. Form, funksjon, fellesskap. Oslo: Universitetsforlaget. 
Lauvland, G. (2007): Verk og vilkår: Christian Norberg Schulz’ stedsteori i et arkitekturfilosofisk perspektiv. Ph.D.avhandling. Oslo: Arkitektur- og designhøgskolen i Oslo.

Lidskog, R. (1998): "Society, Space and Environment. Towards a Sociological Re-conceptualisation of Nature." Scandinavian Housing \& Planning Research, Vol. 15, s. 19-35.

Lindström, B. (1986): "Rummet i samhället. Återvändsgränd eller nyckel till en förnyad samhällsvetenskap." Nordisk Samhällsgeografisk Tidskrift, Vol. 4.

Needham, B. (2000): "Spatial planning as a design discipline: a paradigm for Western Europe." Environment and Planning B: Planning and Design, Vol. 27, s. 437-453.

Norberg-Schulz, C. (1980): Genius Loci: towards a phenomenology of architecture. London: Academy Editions.

Næss, P. \& Saglie, I.-L. (2000): "Surviving between the trenches. Planning research, methodology and theory of science". European Planning Studies, Vol. 8, No. 6, pp. 729-750.

Næss, P. (2004): "Predictions, Regressions and Critical Realism." Journal of Critical Realism, Vol. 2, s. $133-164$.

Næss, P. (2006): "Unsustainable Growth, Unsustainable Capitalism." Journal of Critical Realism, Vol. 5, s. $197-227$.

Næss, P. (2008): "Nyliberalisme i byplanlægningen." I Lundkvist, A. (red.): Dansk nyliberalisme, s 231 - 264. København: Frydenlund.

Purcell, M. (2008): Recapturing Democracy: Neoliberalization and the Struggle for

Alternative Urban Futures. London/New York: Routledge.

Ruud, M. E.; Brattbakk, I.; Røe, P. G. \& Vestby, G. M. (2007): Sosiokulturelle stedsanalyser. Veileder. Oslo: Akershus fylkeskommune.

Saglie, I.-L. (1998): Density and town planning: implementing a densification policy. Dr. ing.-avhandling. Oslo: Arkitekthøgskolen i Oslo.

Sayer, A. (1992) Method in Social Science. A Realist approach, London: Routledge, 2. utgave.

Simonsen, K. (1999): "Rum som social kategori." GRUS, nr. 58, s. 5-22

Strand, A. (1991): Vedlegg til forslag til forskningsprogram om kommunal planlegging. Oslo: Nasjonal komité for miljøvernforskning/NAVF.

Tonboe, J. (1993): Rummets sociologi. Kritik af teoretiseringen af den materielle omverdens betydning $i$ den sociologiske og kulturgeografiske tradition. København: Akademisk forlag.

Tuan, Y.-F. (1979): Space and Place. The Perspective of Experience. London: Edward Arnold.

Vagstein, A. M. (1999): Stedet det stemte rom: sammenhengen mellom sted og arkitektur. Dr. ing.-avhandling. Oslo: Arkitekthøgskolen i Oslo.

van Aken, J. E. (1994): “De bedrijfskunde als ontwerpswetenschap.” (Næringslivsstudier som designfag.) Bedrifskunde, Vol. 66, s. 16-26.

WCED (World Commission on Environment and Development) (1987): Our Common Future. Oxford/New York: Oxford University Press.

Williams, R. H. (1996): Europe Union Spatial Policy and Planning. London: Paul Chapman Publishing.

Østerberg, D. (1998): Arkitektur og sosiologi i Oslo. En sosio-materiell fortolkning. Oslo: Pax.

Østerberg, D. (2002): "Byen som forsvant". Dag Østerberg intervjuet av Morten Ryen. Åpent rom - et blad fra Statsbygg, nr. 2/2002, s. 19.

\section{Noter}

1 Artikkelen er basert på et foredrag under Storbyforskningsprogrammets "Rom-seminar", HiO, 29. april 2008

${ }^{2}$ Bortsett fra det siste spørsmålet, tar de seks spørsmålene utgangspunkt i en behovsforståelse som implisitt forutsetter at det er behov for ny bebyggelse som det så er om å gjøre å lokalisere, utforme og forbinde med andre områder på en god måte. Slik sett bygger de på en menneskesentrert (antroposentrisk) og vekstorientert tankegang, som riktignok kan tenkes å bli modifisert gjennom svarene på det siste og de to første spørsmålene. Denne vekstorienteringen gjenspeiler de politiske rammebetingelsene som lenge har vært rådende for by- og regionplanleggingen både i Norge og internasjonalt. Men som jeg har argumentert for andre steder, vil kontinuerlig vekst i bygningsmasse og bebygd areal neppe kunne være $\varnothing$ kologisk bærekraftig i et langsiktig perspektiv (Høyer og Næss, 2001; Næss, 2006). En bærekraftmotivert begrensning av byggevolum og arealforbruk kunne f. eks. ta utgangspunkt i betraktninger om $\varnothing \mathrm{kologisk}$ fotavtrykk. I stedet for den tradisjonelle tilnærmingen, der arealet som settes av til ikke-utbygging, er det som blir tilbake når hvert av de ulike utbyggingsformålene har fått dekt sin etterspørsel etter byggeareal i planperioden, foreslår Høyer (2008) at man først spør hvor store bioproduktive arealer som trengs for å unngå at våre økologiske fotavtrykk overstiger naturens bæreevne. Konkret dreier det seg om følgende fire arealspørsmål (som har grunnlag i et sett med overordnete volum- eller rom-spørsmål), der svarene vil kreve en normativ fortolkning av hva den globale situasjonen kan/bør innebære i den lokale konteksten:

- Hvor store bioproduktive arealer må avsettes globalt til naturen selv?

- Hvor store bioproduktive arealer er tilgjengelig globalt for menneskelige funksjoner?

- Hvor store bioproduktive arealer bindes i alt opp globalt av alle menneskelige funksjoner, og hvordan står det $\mathrm{i}$ 
forhold til det tilgjengelige?

- Hvor store bioproduktive arealer bindes i alt opp globalt av ulike menneskelige funksjoner?

${ }^{3}$ I senere arbeider har Castells uttrykt et mer nyansert syn på rommets innvirkning på menneskelige handlinger.

"I Norge bl.a. gjennom forskningsprosjektene "Natur og miljøvennlig tettstedsutvikling", "Energi og bygde omgivelser" og "Miljøvern i kommunal planlegging", alle finansiert av Norges Forskningsråd.

${ }^{5}$ Castells, 1977.

${ }^{6}$ Begrepet seriøsitet dreier seg her om i hvilken grad et filosofisk/teoretisk standpunkt er forenlig med det som allment er akseptert som fornuftig praksis. Filosofen David Hume opererte f. eks. med et årsaksbegrep som sammen med hans oppfatning av "induksjonsproblemet" tvang ham til å hevde at det ikke forelå rasjonelle grunner til å velge å forlate en bygning gjennom utgangsdøren i første etasje i stedet for gjennom et vindu i tredje etasje. Det faktum at han selv alltid valgte det første alternativet i stedet for det siste, vitner om at hans filosofiske posisjon manglet seriøsitet.

${ }^{7}$ Norsk oversettelse av profesjonsbetegnelsen "urban designer". I mange engelsktalende land og også bl.a. i Danmark brukes betegnelsen "urban designers" om en yrkesgruppe som er utdannet til å formgi i en geografisk større skala enn hus-tegnende arkitekter, men i mindre skala enn byplanleggere og med fokus primært på de estetisk/visuelle aspektene ved bymiljøet.

${ }^{8}$ I norsk sammenheng er trolig Inger-Lise Saglies (1998) doktoravhandling det arbeidet innenfor arkitektur/planforskning som går grundigst inn på rombegrepet og dets anvendelse i forskning og planlegging. Saglie benytter en kombinasjon av flere rombegreper, med særlig vekt på opplevd rom og relativt rom.

9 Se Høyer \& Næss (2008) for en utdypende drøfting av den tendensen visse metateoretiske perspektiver har til å utelukke deler av virkeligheten som det f. eks. i tverrfaglig miljøforskning vil være vesentlig å inkludere. 